удк 342.6

DOI https://doi.org/10.32837/pyuv.v0i2(31).574

\author{
Т. А. Кравченко \\ orcid.org/0000-0002-4912-3498 \\ кандидат політичних наук, \\ доиент кафедри політологї \\ Міжрегіональної академії управління персоналом
}

\title{
ПРИРОДНО-ПРАВОВА МОДЕЛЬ ЛЕГІТИМНОСТІ ДЕРЖАВНОЇ ВЛАДИ
}

Актуальність теми. На основі концепції легітимності влади, яку розробили та систематизували представники Нового часу, у XIX ст. були представлені дві основні моделі легітимності державної влади: природно-правова модель і модель легітимності представників теорії юридичного позитивізму.

Значний внесок у формування правової теорії легітимності зробили представники школи природного права, які на початок XIX ст. доповнили та розвинули правову концепцію Г. Гроція, надавши їй більш практичного застосування. В основу природно-правової доктрини легітимності була покладена ідея природного права (природних прав людини). Саме ця ідея стала тим критерієм легітимності, на основі якого оцінювалася діяльність державної влади, іï рішення та закони [1, с. 106].

Виклад основного матеріалу. Принципово важливе значення для розвитку теорії правової держави мала творчість І. Канта. Як і багато інших тогочасних мислителів, він вважав, що держава прийшла на зміну природному станові, у якому не було ніякої гарантії законності. Моральний борг, почуття поваги до природного права спонукають людей полишити цей стан і шляхом суспільного договору перейти до життя у громадянському суспільстві, державі. Суспільний договір укладають між собою морально розвинені люди, тому державі забороняється поводитися з ними як з істотами, що не знають морального закону і не можуть самі обрати правильну лінію поведінки. Зі свого боку, народ повинен підпорядковуватися державі, встановленим нею законам.

I. Кант у низці своїх трактатів послідовно відтворює структурні рівні порядку суспільства, пов'язані із природою людини. Борг, виражений у моральному законі, з'являється як апріорний факт чистого розуму і є підставою морального порядку. Без моральної основи неможливо, на думку I. Канта, вибудувати політичний порядок.

Справжню свободу, вважав I. Кант, люди дістають лише в державі. Однак нерідко свобода переростає у свавілля. Сукупність умов, які обмежують свавілля одного стосовно інших, І. Кант називає правом. Здійснення права вимагає, щоб воно було загальнообов'язковим. Для цього потрібно наділити право силою примусу, що може зробити лише держава. I. Кант визначає державу як «об'єднання множинності людей, підпорядкованих правовим законам» [2, с. 233].

Призначення держави він пов'язує не із практичними потребами членів суспільства, а із правом - державний устрій повинен максимально відповідати вимогам досконалого права.

Висунення й обгрунтування I. Кантом тверджень про те, що кожна людина є абсолютною і самодостатньою цінністю, що індивіди відмовляються від необмеженої та свавільної свободи природного стану на користь справжньої свободи у правовому стані, що призначення держави полягає в досконалому праві, максимальній відповідності державного устрою принципам права тощо, дають підстави вважати його одним із творців теорії правової держави.

Так поступово сформувалася теорія правової держави, сенс якої полягає в обгрунтуванні необхідності зв'язати державу правом, установити правові межі їі могутності та тим самим захистити громадян від можливого свавілля з боку держави, не допустити виродження держави в тиранію. Згідно з теорією правової держави закон мусить бути єдиним для всіх - i для держави, i для громадян - i мати правовий характер, тобто відповідати високим моральним вимогам. Державне правління, засноване на законах, може мати й деспотичний характер, якщо закони не відповідають вимогам моральності, гуманізму, демократизму і справедливості та спрямовані лише на захист державної влади.

На думку I. Канта, громадський порядок, заснований на пануванні верховної влади над громадянами, не може бути стійким і довговічним. Відповідно до I. Канта виявляється неспроможною ідея порядку суспільства, заснована на народному суверенітеті, не пов'язаному із правовою державою. Ця ідея приховує у собі небезпеку найбільшого деспотизму [3, с. 79].

Держава, за В. Гумбольдтом, повинна обмежуватися винятково встановленням зовнішньої та внутрішньої безпеки. Будь-яке сприяння добробуту громадян із боку держави неможливе без втручання її у всі галузі людського життя. А подібне втручання, як боявся В. Гумбольдт, обмежить особисту свободу і перешкодить своєрідному розвит- 
ку індивіда. Вищу мету, яка повинна визначати межі діяльності держави, філософ бачив в універсальному розвитку індивідуальності [4, с. 131].

Сам термін «правова держава» з'явився в XIX ст. у німецькій літературі у працях К.Т. Велькерах і Р. Моля. Створення юридично завершеного поняття «правова держава» пов'язують з ім'ям Р. Моля. У 1829 р. він дав визначення правової держави як конституційної держави, яка повинна спиратися на закріплені в конституції права і свободи громадян, на забезпечення судового захисту особи [5, с. 164].

Надалі ідея легітимності логічно розвинулася у державно-правових поглядах відомого українського вченого-юриста, представника соціологічної школи права, професора Київського університету Б.О. Кістяківського. Учений висловлює свої погляди про народний суверенітет через призму вчення про правову (конституційну) державу. Остання, на його переконання, грунтується на основі гармонійного поєднання двох основоположних принципів - прав і свобод людини та народного суверенітету: «У правовій державі влада повинна бути організована так, щоб вона не пригнічувала особистість; у ній як окрема особистість, так і сукупність особистостей - народ - повинні бути не тільки об'єктом влади, алеіїї суб'єктом» [6, с. 330].

Як зазначав Б.О. Кістяківський, у конституційній державі влада безпосередньо пов'язана 3 народом, оскільки сам народ бере безпосередню участь в організації влади та створенні її органів. У конституційній державі уряд і народ не можуть протиставлятися як щось протилежне та вороже один одному. Водночас вони не зливаються повністю і не уособлюють щось нероздільно існуюче. Навпаки, державна влада в конституційній державі залишається цілісною, неподільною владою і зберігає своє власне, самостійне значення та існування. Але ця влада солідарна з народом, оскільки їхні завдання та цілі одні і ті самі, їхні інтереси значною мірою спільні: «Єдність влади з народом $€$ завжди ціллю й основною метою будь-якого конституційного уряду» [6, с. 331].

Визначний внесок у формування легітимності публічної влади здійснили французькі мислителі XIX ст. Б. Констан, Ф. Гізота, А. де Токвіль. Вони одними з перших запровадили у політико-правовий лексикон поняття «легітимність» у його сучасному розумінні.

Основне питання їх інтелектуальних пошуків зводилося до такого: чи завжди воля народу, про яку писав їхній співвітчизник Ж⿱.-ЗЖ. Руссо, має легітимний характер і як зробити управління суспільством ефективним, зберігши свободу й основні правові гарантії громадян? Так, Б. Констан, Ф. Гізо й А. де Токвіль вважали, що політична влада - це явище соціальне, адже індивіди вступають у відносини один з одним не завдяки юри- дичним законам, а навпаки, закони є продуктом суспільних відносин [7, с. 62].

На переконання Б. Констана, не народний суверенітет, а права та свободи людини є основним мірилом легітимності. Саме останні виступають тим критерієм, на основі якого можна констатувати легітимний характер влади. «Наділіть носіїв виконавчої влади правом зазіхати на індивідуальну свободу, і ви знищите всі гарантії, які були першою умовою і єдиною ціллю об’єднання людей під владою законів» [8, с. 180].

На думку філософа, всі громадяни незалежно від волі державної влади володіють індивідуальними правами, які передбачають: особисту свободу, свободу совісті, свободу думки та слова, право власності.

Відстоюючи у своїх працях ідею про те, що права та свободи людини є основним критерієм легітимності державної влади і що будь-яке беззаконня щодо особистих прав, навіть те, що санкціоноване народним суверенітетом, не має нічого спільного з легітимацією, Б. Констан закладав основи ліберально правової концепції легітимності влади, котра стала популярною в XIX ст. не лише у Франції, а й у інших країнах Європи [7, с. 64].

На думку Ф. Гізо, єдиним джерелом легітимності за природою є розум, істина та справедливість, легітимність влади перебуває поза межами суспільства, а верховна влада не має політичної природи. Принципово важливий елемент концепції Ф. Гізо - твердження про неможливість пізнання абсолютної істини, внаслідок якої єдино легітимна влада не зможе повністю бути втілена на землі у тій чи іншій формі правління [9, с. 515].

Абсолютної суверенної влади, так само як i абсолютної легітимності, не існує, незважаючи на те, що правителі часто намагаються досягти за допомогою сили такого земного правління. «Жоден народ не визнав владу лише через її силу, він хотів вірити в їі легітимність, божественність. Жодна влада не задовольняється лише однією силою; вона потребувала того, щоб їі визнали легітимною та божественною. Що ще потрібно для того, щоб довести, що суверенітет належить одній тільки істині, справедливості, одному лише Богу» $[9$, с. 515].

Ф. Гізо спробував запропонувати свою теорію легітимності, яка б не грунтувалася ні на принципі народного суверенітету Ж⿱.-Ж. Руссо, ні на принципі особистої свободи Б. Констана. Джерелом легітимності є не суспільні відносини, а вищий Розум, яким є Бог. Суть політичної легітимності Ф. Гізо характеризує у такий спосіб: «Вона є не що інше, як презумпція моральної легітимності; презумпція, яка встановлюється щодо державної влади за двох умов. Перша - щоб вона певною мірою задовольняла головні нагальні потреби, тобто щоб вона володіла певною частиною дійсної легі- 
тимності; друга - щоб через певний час публічно влада отримала схвалення» .

Аналізуючи концепцію легітимності державної влади, необхідно згадати вчення ще одного французького мислителя А. де Токвіля, викладене у відомій праці «Про демократію в Америці». Він вважав, що для сучасних демократій надзвичайно важливо, щоб такий принцип не порушував особисті права та свободи особи: «Тому саме за часів демократії справжні поборники свободи й величі людини мають негайно і рішуче перешкодити тому, аби суспільна влада могла принести в жертву окремі права кількох громадян в ім'я реалізації своїх глобальних задумів» [10, с. 571].

Як саме необхідно будувати відносини у демократичному суспільстві, А. де Токвіль коротко виклав в одній зі своїх тез: необхідно надати державній владі доволі широкі, але зрозумілі й визначені повноваження; дати приватним особам конкретні права й гарантувати їм незаперечну змогу користуватися цими правами.

Важливим суб'єктом легітимації державної влади та гарантом прав і свобод людини є громадянське суспільство. Через політичні асоціації, незалежну пресу органи самоврядування в демократичному суспільстві (А. де Токвіль має на увазі США) представляють інтереси народу перед владою і контролюють їі. Особливе місце у формуванні демократичного суспільства з високим рівнем культури належить релігії. Вона $є$ «охоронцем моралі», яка $\epsilon$ «кращим охоронцем права і запорукою свободи» [7, с. 67].

Тобто вищенаведене дає нам змогу зробити висновок, що вчення А. де Токвіля виокремлюється серед інших представників французької політико-правової думки тим, що він вважає громадянське суспільство не лише індикатором легітимності влади, але і їі джерелом, рушійною силою, яка безпосередньо впливає на формування державної влади та здійснення контролю за нею.

Дослідників соціологічної школи права, німецьких державознавців Р. Ієрінга і Г. Єллінека, по праву можна вважати творцями правової теорії легітимності.

Відповідно до вчення Р. Іерінга основне покликання держави - здійснення суспільного примусу, оскільки держава, за словами вченого, є «організацією соціального примусу». Метою такого примусу, як це випливає з праці «Мета в праві», забезпечення суспільних інтересів, і досягнення цієї мети покладається на державну владу та право. У цьому контексті Р. Іерінг детально аналізує сутність державної влади та порядок її застосування. Для реалізації державної мети державна влада повинна стояти вище за всі інші влади через те, що наділена найбільшою силою: «Безсилля, неміч державної влади - смертельний гріх держави...» $[11$, с. 285$]$.
Засобом здійснення примусу державною владою є право, яке, за визначенням дослідника, $€$ «сукупністю діючих у державі примусових норм».

Державна влада та право тісно взаємозв'язані між собою: влада набуває реальної сили лише завдяки праву, тоді як право набуває своєї реалізації лише через діяльність держави. Більше того, Р. Ієрінг висловлює твердження, притаманне представникам саме юридичного позитивізму, про те, що «держава є єдиним джерелом права».

Головна мета державної влади відповідно до ідей німецького вченого - здійснення примусу, або реалізація права, натомість метою права є задоволення інтересів індивідів всередині суспільства. Право - це юридично захищений інтерес, тому при захисті будь-яких інтересів першочергово вирішується питання узгодженості інтересів індивіда та суспільства.

Отож, у державно-правовій доктрині Р. Ієрінга держава посідає домінуюче місце щодо права: по-перше, право виявляється зобов'язаним державі не лише своїм походженням, а й способом існування; по-друге, право є фактично тотожним закону; по-третє, право зводиться до сукупності примусових норм і $є$ «політикою влади».

За допомогою права державна влада здійснює процес панування однієї групи людей над іншою, що набуває легального характеру. Найвищий рівень владарювання заснований на двосторонній обов'язковій силі правової норми, таке владарювання передбачає, що державна влада визнає прийняті нею правові норми обов'язковими і для самої себе. Саме наведена умова забезпечує правомірний характер державної влади, оскільки «хто узгоджує свої дії з вимогами права або закону, той діє правомірно, законно, легально, в іншому разі - протиправно, протизаконно, незаконно, нелегально» [11, с. 307].

Всі ці поняття можна застосовувати як до державної влади, так і до підданих. Р. Іерінг ототожнюе правомірність (легітимність) із законністю (легальністю), оскільки легальна влада, тобто така, що діє в межах чинного закону, є одночасно і легітимною (правомірною).

Ще одним представником теорії юридичногопозитивізму, у працях якого проблема легальності та легітимності державної влади стала однією із ключових, є німецький вчений-державознавець Георг Єллінек. До речі, першість у використанні поняття «легітимність» («правомірність») у державному праві Німеччини належить саме Г. Єллінеку.

На думку німецького вченого, право необхідно розглядати одночасно і як сукупність норм, що спираються на зовнішній примус, і як норми, які є загальновизнаними, а тому і гарантованими суспільством. Інакше кажучи, право досягає своєї мети як через мотивацію, побудовану на почутті страху перед можливим застосуванням 
санкцій, так і через повагу до нього як до «етичного мінімуму». По суті, Г. Єллінек закладав основи інтегративної теорії право розуміння, яка намагалася примирити між собою позитивне та природне право [12, с. 35].

Г. Єллінек пропонує свою власну концепцію легітимності публічної влади та права, що сформувалася на основі критики попередньої теорії легітимації, протагоністами якої були прихильники династії Бурбонів у Франції. Він, по суті, розвиває iii. У Г. Єллінека «легітимність» означає правомірність у природно-правовому сенсі, тобто відповідність соціальної практики уявленням більшості її суб'єктів про справедливість або розумність такої практики. «Зерно істини, - пише автор, - містить у собі і теорія легітимізму, яка виводить право із тривалого визнання фактичних відносин» [13, с. 342].

Джерелом легітимності державної влади та права, на думку вченого, можуть бути не лише традиції та звичаї, а й уявлення про природно-правовий порядок чи про природне право. У силу своєї внутрішньої справедливості та моральності уявлення про таке право завжди міститься у психіці людини, тому завдяки своєму моральному потенціалу воно завжди залишається дієвим. Уявлення про природне право енергійно сприяє легалізації навіть найглибших і швидко здійснюваних перетворень державного і правового ладу. Переконання в розумності нового порядку створює уявлення про його правомірність. Цим можна пояснити примус, що довго тривати не може, тому що він набуває характеру звичайно-правового, або ж цей виключно зовнішній порядок руйнується. Саме усвідомлення фактично існуючого порядку правовим надає державній владі легітимний (правомірний) характер і робить їі стійкою та тривалою: «Державна влада повинна - не рахуючи перехідних епох - спиратися на переконання народу в її правомірності, що стосується будь-якої форми держави, не виключаючи і необмеженої монархї̈» [13, с. 410].

Нормативісти (легісти), погляди яких найбільш повно викладені у працях Г. Кельзена, взагалі ототожнювали поняття «легітимність» $\mathrm{i}$ «легальність» і вважали, що будь-яка легальна влада автоматично є і легітимною.

Найвідоміший представник правового позитивізму, родоначальник «чистого вчення про право» Г. Кельзен розглядає державу як нормативний правопорядок і трактує легітимність як відповідність дії влади формальній правовій нормі. Для Г. Кельзена характерне зміщення центру ваги у розумінні права з волі суверена на суспільне визнання правил поведінки. Правові норми наділяються властивістю легітимності, обгрунтованості, виражаються у ставленні до них громадян. Він виводить право не 3 волі держави, а з «основної норми». «Згідно 3 основною нормою державного правопорядку ефективний уряд - це той уряд, який на підставі чинної конституції створює дієві загальні та індивідуальні норми. Його можна вважати легітимним урядом держави», - писав Г. Кельзен [14, с. 226].

Питання легітимності державної влади висвітлене у працях ще одного німецького юриста, соціолога Макса Вебера. Саме він застосував системний аналіз легітимності як фундаментальної властивості влади загалом, так і державної влади зокрема. Будучи яскравим представником юридичного позитивізму, М. Вебер у своєму аналізі державної влади, подібно до Г. Єллінека, вчення якого мало на нього неабиякий вплив, поєднував як юриспруденцію, так і соціологію.

М. Вебер у праці «Господарство і суспільство» визначає три «ідеальні типи» легітимності влади, наголошуючи, що поняття «легітимна влада» й «авторитет»- синоніми. Учений вводить у соціологію поняття «визнання» і перетворює його на категорію «орієнтація на іншого», що виявилося визначальним моментом соціальної дії. Сучасне суспільство, приймаючи правила легітимації влади, передбачає можливість різного розуміння ïi сенсів, де кожен із них може бути соціально визнаним, що означає - цінним та авторитетним.

Вчений виділяє особливу форму влади - панування, під яким розуміється здатність забезпечувати порядок і підкорення шляхом застосування чи загрози застосування фізичного чи психічного насилля. У структурі панування вчений розрізняє три елементи: пануючу меншість, апарат управління та підпорядковану пануванню меншості масу [15, с. 18].

М. Вебер виділяє три джерела легітимності влади: традицію, харизму та раціональність. Ним було виділено три чисті типи легітимного панування: традиційне, харизматичне та раціонально-правове.

3 цього приводу М. Вебер у своїй праці «Господарство та суспільство» пише таке: «Існує три чисті типи легітимного панування. Їх легітимність може бути: 1) раціонального характеру, тобто базуватися на вірі в легальність встановленого порядку і законність здійснювання панування на основі цієї легальності (легальне панування); 2) традиційного характеру, тобто заснована на звичайній вірі у святість традицій і вірі в легітимність авторитету, що побудований на цих традиціях; 3) харизматичного характеру, тобто базуватися на неабияких проявах святості або геройської сили, чи зразковості особистості та створеному цими проявами порядку (харизматичне панування)» [16].

Як вважав М. Вебер, основними засадами раціонально-правової легітимності є такі: а) будьякі закони приймаються і можуть за бажанням змінюватися із дотриманням певних формальних процедур; б) члени об’єднання, яке здійснює владу, можуть обиратися або ж призначатися, саме це об'єднання та всі його частини є підприємствами; 
в) окремі гетерономні й гетерокефальні підприємства такого роду називають органами влади, або владними установами; г) управлінський штаб складається із чиновників, що призначаються керівництвом, а підлеглі вважаються членами владного об'єднання (тобто громадянами) [17, с. 121].

Таким чином, за легального типу панування джерелом легітимності виступає інтерес, що раціонально стимулює людей підкорятися не особі керівника, а праву, в рамках якого обираються i діють представники влади в демократичних державах. Це безособовий (деперсоніфікований) формально-правовий принцип, якому підкоряються не лише керовані, але i керівники (чиновники, бюрократія).

Наступним типом легітимного панування $€$ традиційний тип, який заснований на вірі у звичай, у священну дію спрадавна існуючих порядків і влад. Такий тип схожий на стосунки в патріархальній сім'ї, де традиції добровільного підпорядкування старшим особливо міцні та стійкі. Традиційне панування характерне для феодальної Європи і Сходу, для монархічних форм правління. Але Вебер вважав, що і для Заходу, для стабільності демократії корисне збереження монарха, що підкріплює авторитет держави багатовіковими традиціями шанування влади [18, с. 175].

Третім ідеальним типом легітимного панування у класифікації М. Вебера є харизматичне панування. Харизматичний (від грецьк. charisma божественний дар) тип влади грунтується на вірі у виняткові якості керівника, дані йому зверху Богом або природою. Прикладом може бути популярність генерала Ш. де Голля у Франції, який перший почав використовувати поняття «легітимність» щодо політичної влади. Зазвичай, коли сьогодні застосовується поняття "харизма», воно тлумачиться виключно як специфічна здатність особи концентрувати навколо себе політичну енергію і тим самим спрямовувати маси на певні дії. Однак насправді для М. Вебера харизматичне панування - це не просто зв'язок «вождь - послідовники», але й доволі складна управлінська технологія, яка передбачає постійне збереження та підтримання харизми.

Саме тому за умов харизматичної легітимності ми часто спостерігаємо формування різноманітних культів особистості, що не стільки породжуються марнославством чи будь-якими іншими індивідуальними властивостями харизматичного лідера, як постають результатом об'єктивної необхідності політико-технологічного підтримання харизми, котра, по суті, виступає основою як легітимності лідера, так і легітимності тих рішень, що ним приймаються.

Вклад М. Вебера у систематизацію легітимності державної влади важко переоцінити, він вивів теорію легітимації влади на новий науковий рівень. У цьому сенсі цілком слушною видається теза В.А. Бачиніна, який зазначає, що незважаючи на те, що сам термін «легітимність державної влади» доволі активно використовувався ще у XVII - XVIII ст. (насамперед варто згадати французьку політичну традицію, де саме через визнання легітимності королівської влади робилися теоретичні спроби обгрунтувати їі незмінність), концептуально розроблене це поняття лише в дослідженнях М. Вебера [19, с. 126].

Проблема легітимності державної влади була також предметом розгляду російських та українських дослідників. Видатний російський юрист M.М. Коркунов, котрий розробив психологічну теорію права, вважав, що однією з основних опор будь-якої державної влади є почуття законності. Він писав: "Авторитет наказів влади базується завжди, зрештою, на визнанні їх обов'язковості з боку суспільства. Кожен окремий громадянин змушений підкорятися наказам органів влади не лише тому, що той, хто наділений владою, цього вимагає, але й тому, що все суспільство визнає ці накази обов' язковими» [20, с. 286].

На думку вченого, державна влада не є безумовною й абсолютною, тому, усвідомивши необхідність їй підкорятися, людина одночасно усвідомлює, що органи державної влади зобов' язані у процесі здійснення своїх функцій дотримуватися юридичних норм, які розмежовують інтереси влади й інтереси особи й суспільства. У конституційно-правовій демократичній державі вся повнота влади належить народу, котрий не лише формує, але й здійснює контроль за публічною владою. Характерною ознакою такої держави є злиття суб'єкта й об'єкта владних відносин в одне політичне ціле, оскільки народ як єдине джерело влади є водночас і владарюючим, і підвладним.

Розглянувши модель представників теорії юридичного позитивізму, доходимо висновку, що найповніше проблема легітимності державної влади була висвітлена основоположниками соціологічної школи права.

\section{Jimepamypa}

1. Ковальчук В.Б. Легітимність державної влади: теоретико-правові аспекти : дис ... докт. юрид. наук : 12.00.01. Харків, 2011. 447 с.

2. Кант И. Метафизика нравов в двух частях. Ч. 1. Метафизические начала учения о праве. Сочинения : в 6 т. Москва, 1965. Т. 4. Ч. 2.

3. Кант И. Сочинения : в 6 т. Т. 4. Ч. 2 / под ред. В.Ф. Асмуса. Москва : Мысль, 1965. 478 с.

4. Гумбольдт В. О пределах государственной деятельности. Челябинск : Социум, 2009. 287 с.

5. Кельман М.С., Мурашин О.Г., Хома Н.М. Загальна теорія держави та права : підручник. Львів : «Новий Світ-2000», 2003. 584 с.

6. Кистяковский Б.А. Философия и социология права. Санкт-Петербург : РГХИ, 1999. 800 с.

7. Ковальчук В.Б., Богів Я.С. Правова доктрина народного суверенітету та легітимності державної влади 
у Франції в період XIX століття. Вісник Національного університету «Львівська політехніка». Юридичні науки. 2015. № 827. С. 61-68.

8. Констан Б. Принципы политики. Классический франиузский либерализл. Москва : Российская политическая энциклопедия, 2000. С. 23-262.

9. Гизо Ф. Политическая философия: о суверенитете. Классический французский либерализл. Москва : Российская политическая энциклопедия, 2000. С. 507-588.

10. Токвіль А. де. Про демократію в Америці : у 2 т. / пер. з фр. Г. Філіпчука, М. Москаленка. Київ : Всесвіт, 1999. 590 с.

11. Иеринг Р. Цель в праве. Избранные труды : в 2 т. Санкт-Петербург : Юридический центр Пресс, 2006. T. I. 624 c

12. Ковальчук В.В. Проблема легітимності та легальності влади в державно-правових доктринах Р. Ієрінга та Г. Елліника. Юридична Украӥна. 2011. № 8. C. $32-38$.

13. Еллинек Г. Общее учение о государстве / вступ ст. И.Ю. Козлихина. Санкт-Петербург : Юридический центр Пресс 2004. 1050 с.

14. Кельзен Г. Чистое учение о праве / пер. с нем. М.В. Антонова и С.В. Лёзова. Санкт-Петербург : Издательский Дом «Алеф-Пресс», 2015. 542 с.

15. Ковальчук В., Богів Я. Вчення про легітимність влади та народний суверенітет в державно-правових поглядах представників соціологічної школи права в Нiмеччині у другій половині XIX - першій чверті XX століття. Iсторико-правовий часопис. 2015. № 2 (6). С. 15-20.

16. Вебер M. Хозяйство и общество. URL http://filosof.historic.ru/books/item/f00/s00/ z0000306/index.shtml.

17. Кант И. Метафизика нравов в двух частях. Ч. 1. Метафизические начала учения о праве. Сочинения : в 6 т. Москва, 1965. Т. 4. Ч. 2.

18. Левчук I.I. Легітимність влади як детермінанта соціально-політичного порядку. Актуальні проблеми політики. 2011. Вип. 12-18. С. 174-182.

19. Бачинин В.А. Политология. Энииклопедический словарь. Санкт-Петербург : Изд-во Михайлова В.А., 2005. 288 c.

20. Коркунов Н.М. Лекции по общей теории права. Санкт-Петербург : Юридический центр Пресс, 2003. 430 с.

\section{Анотація}

Кравченко Т. А. Природно-правова модель легітимності державної влади. - Стаття.

У статті розглядаються природно-правові моделі легітимності державної влади. Досліджуються дві основні моделі легітимності державної влади: природно-правова модель і модель легітимності представників теорії юридичного позитивізму, детально проаналізовані концепції кожної з цих моделей. 3'ясовано, що принципово важливе значення для розвитку теорії правової держави мала творчість I. Канта. Як і багато інших тогочасних мислителів, він вважав, що держава прийшла на зміну природному станові, в якому не було ніякої гарантії законності. Моральний борг, почуття поваги до природного права спонукають людей полишити цей стан і шляхом суспільного договору перейти до життя у громадянському суспільстві, державі. Суспільний договір укладають між собою морально розвинені люди, тому державі забороняється поводитися з ними як з істотами, котрі не знають морального закону і не можуть самі обрати правильну лінію поведінки. Визначено, що висунення й обгрунтування I. Кантом тверджень про те, що кожна людина є абсолютною і самодостатньою цінністю, що індивіди відмовляються від необмеженої та свавільної свободи природного стану на користь справжньої свободи у правовому стані, що призначення держави полягає в досконалому праві, максимальній відповідності державного устрою принципам права тощо дають підстави вважати його одним із творців теорії правової держави. Доходимо висновку, що найповніше проблема легітимності державної влади була висвітлена основоположниками соціологічної школи права. Характерними ознаками концепції легітимності державної влади соціологічної школи права $€$ ототожнення поняття «легітимність» і «легальність»: вважається, що будь-яка легальна влада автоматично є і легітимною; лише легальна, раціональна влада має легітимний характер; влада належить народу, який не лише формує, але і здійснює контроль за публічною владою, влада і народ виступають як єдине політичне ціле. Державна влада не є безумовною й абсолютною, тому, усвідомивши необхідність їй підкорятися, людина одночасно усвідомлює, що органи державної влади зобов'язані у процесі здійснення своїх функцій дотримуватися юридичних норм, які розмежовують інтереси влади й інтереси особи та суспільства.

Ключові слова: державна влада, легітимність, демократія, публічна влада, державні гарантії, права і свободи людини, законність, джерела права.

\section{Summary}

Kravchenko T. A. Natural-legal model of legitimacy of state power. - Article.

In article natural and legal models of legitimacy of the government are considered. Two main models of legitimacy of the government are investigated: the natural and legal model and model of legitimacy of representatives of the theory of legal positivism, detail analyzed concepts of each of these models. It was found that the work of I. Kant was of fundamental importance for the development of the theory of the rule of law. Like many other thinkers of the time, he believed that the state replaced the natural state, in which there was no guarantee of legitimacy. Moral duty, a sense of respect for natural law motivate people to leave this state and through a social contract to move to life in civil society, the state. The social contract is concluded between morally developed people, so the state is forbidden to treat them as beings who do not know the moral law and can not choose the right course of action. It is determined that I. Kant's statement and substantiation of claims that each person is an absolute and self-sufficient value, that individuals refuse unlimited and arbitrary freedom of natural state in favor of true freedom in the legal state, that the purpose of the state is perfect law, maximum compliance state system, the principles of law, etc., give reason to consider him one of the main creators of the theory of the rule of law. As a result, we draw the conclusion that most fully the problem of legitimacy of the government was covered by founders of sociological school of the law. Characteristic signs of the concept of legitimacy of the government of sociological school of law is the identification of the concept "legitimacy" and "legality" it is considered that any legal power automatically is also legitimate; only the legal, rational power has legitimate character; the power belongs to the people which not only create, but also exercises control of the public power, the power and the people act as uniform political whole. The state power is not insane, absolutely, therefore, having grasped the need to grow up, people immediately learn how to organize the power of the state in the process of building up their functions to achieve the norm.

Key words: government, legitimacy, democracy, public power, state guarantees, rights and freedoms of the person, legality, sources of law. 